\section{Amplification of DNA from Whole Cells of Cya- nobacteria Using PCR}

BioTechniques 21:32-34 (July 1996)

Cyanobacteria are gram-negative bacteria with a thick peptidoglycan layer (2) that makes them resistant to disruption, without the addition of detergents, which inhibit polymerase chain reaction (PCR), or other methods of cell disruption (e.g., sonication). This has meant that whole cells have not been used as a template for PCR as is the case in other organisms (4). A simple, rapid method is presented here that uses a single colony of Anabaena PCC 7120 from a plate as the template for PCR. This method allows for rapid screening of large numbers of potential transformants in insertional inactivation studies to determine if they are fully segregated. Previously, after screening for double recombinants on sucrose (1), potential transformants had to be grown in liquid culture. Their genomic DNA had to be isolated and used as the template for PCR or Southern blot analysis to determine if the transformants were completely segregated (3).

A single colony of Anabaena PCC 7120 from a plate was resuspended in $100 \mu \mathrm{L}$ of sterile demineralized water (Millipore, Sydney, Australia), giving an approximate cell density of $8 \times 10^{4}$ to $8 \times 10^{6}$ cells $/ \mathrm{mL}$. Three microliters of the resulting cell suspension were used in a $10-\mu \mathrm{L}$ reaction containing bovine serum albumin (BSA) (0.1 $\mathrm{mg} / \mathrm{mL}), 1 \times$ amplification buffer containing $1.5 \mathrm{mM} \mathrm{MgCl}_{2}$ (Boehringer Mannheim, Sydney, Australia), 0.2 $\mathrm{mM}$ dNTPs, 20 pmol of each primer and 0.5 U Taq DNA Polymerase (Boehringer Mannheim). PCR was carried out by using a FTS-1 capillary thermal cycler (Corbitt Research, Sydney, Australia), and reactions were performed in sealed capillary tubes. The following program was used for amplification of DNA: $94^{\circ} \mathrm{C}$ for $5 \mathrm{~min}$, followed by 30 cycles of $94^{\circ} \mathrm{C}$ for $1 \mathrm{~min}, 80^{\circ} \mathrm{C}$ for $15 \mathrm{~s}$, $65^{\circ} \mathrm{C}$ for $15 \mathrm{~s}$, annealing at $55^{\circ} \mathrm{C}$ for 1.5 $\min , 65^{\circ} \mathrm{C}$ for $15 \mathrm{~s}, 72^{\circ} \mathrm{C}$ for $2.5 \mathrm{~min}$ and $85^{\circ} \mathrm{C}$ for $15 \mathrm{~s}$. This was followed by one cycle of $94^{\circ} \mathrm{C}$ for $1 \mathrm{~min}, 72^{\circ} \mathrm{C}$ for $5 \mathrm{~min}$ and $25^{\circ} \mathrm{C}$ for $1 \mathrm{~min}$. The $15-\mathrm{s}$ incubations at temperatures in between the denaturing $\left(94^{\circ} \mathrm{C}\right)$, annealing $\left(55^{\circ} \mathrm{C}\right)$ and extension $\left(72^{\circ} \mathrm{C}\right)$ steps were included to simulate slower ramping rates, as without these steps, no PCR products could be seen (data not shown). This indicates that the method may be suitable for use in any type of thermal cycler, provided appropriate modifications are made to take into account the slower ramp rate in non-capillary thermal cyclers. In regard to this, the amplification has also been performed successfully by using an FTS960 thermal cycler (Corbitt Research), using 0.2-mL tubes and a ramp rate of 3 $\mathrm{s} /{ }^{\circ} \mathrm{C}$ between the denaturing and annealing steps. PCR products were visualized by ethidium bromide staining after agarose gel electrophoresis.

The results of a typical reaction in which part of the operon encoding $n d h C-K-J$ from Anabaena PCC 7120 was amplified, by using primers identical to regions in $n d h C$ and $n d h J(5)$, are shown in Figure 1. Wild-type genomic DNA, isolated as described (6), that had been passed through cesium chloride gradients was the template in lane a, and, as expected, a single product of approximately $1.3 \mathrm{~kb}$ was seen. Lanes b, c and d show that there were two major products seen as a fragment of approximately $1.3 \mathrm{~kb}$ and one of approximately 500 bp when 1,3 and $5 \mu \mathrm{L}$ of the cell suspension were used as the template. Some minor products of lower molecular weight were also seen in lanes b, c and d that were not present in lane a. This indicates that there was some nonspecific priming when whole cells were used as a template. The presence of the $1.3-\mathrm{kb}$ fragment, which is seen when genomic DNA is used as the template in the whole-cell reactions, indicates that this technique successfully amplified the sequence of interest. Interestingly, it was found that the yield of the PCR decreased with increasing time after resuspension of the cells in water. The experiment described above was repeated $24 \mathrm{~h}$ after resuspension of the cells, and the major product could only just be visualized after staining with ethidium bromide. However, the product was clearly visible in the control lane with genomic DNA as the template (data not shown).

Fragments up to $2.6 \mathrm{~kb}$ have been amplified successfully from Anabaena PCC 7120 by using the protocol described above. The cell density used in the amplification reaction does not appear to be critical, and in most cases it is sufficient to resuspend a single colony in $100 \mu \mathrm{L}$ and use $3 \mu \mathrm{L}$ of this suspension as the template for the amplification. Preliminary trials with Synechococcus PCC 7942 and Synechocystis PCC 6803 have shown that this method can also be used with these species and thus may be a general method applicable to all cyanobacteria. As with Anabaena PCC 7120, when using Synechococcus PCC 7942 as the

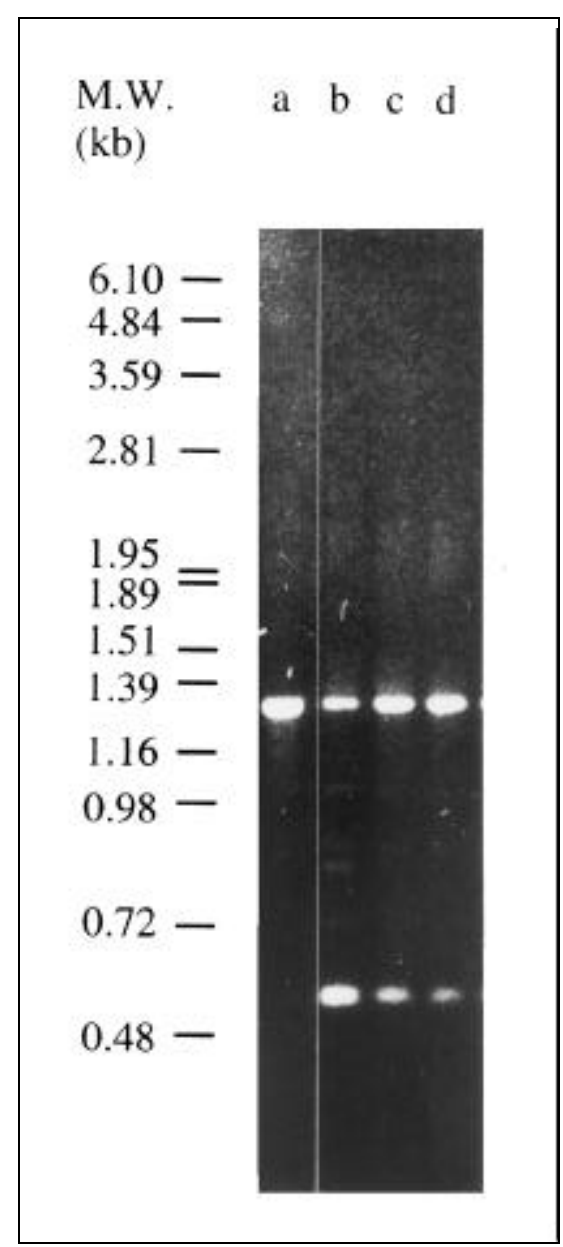

Figure 1. Amplification of $n d h K$ from Anabaena 7120 by PCR, using whole cells as the template. A single colony of Anabaena PCC 7120 from a plate was resuspended in $100 \mu \mathrm{L}$ of demineralized water, and aliquots of the cell suspension were used as the template for PCR. Lane a contained $100 \mathrm{ng}$ of CsCl-purified genomic DNA from Anabaena 7120, which was used as the template. Lanes b, c and d contained 1, 3 and $5 \mu \mathrm{L}$, respectively, of the cell suspension as the template. 


\section{Benchmarks}

template, the cell density does not appear to be critical. Successful amplifications have been performed when the density of the resuspended cells was between $1 \times 10^{5}$ and $1 \times 10^{7}$ cell $/ \mathrm{mL}$. With Synechocystis PCC 6803, the primer-to-cell density ratio appears to be critical and must be empirically determined for each set of primers used.

\section{REFERENCES}

1.Cai, Y. and C.P. Wolk. 1990. Use of a conditionally lethal gene in Anabaena sp. strain PCC 7120 to select for double recombinants and to entrap insertion sequences. J. Bacteriol. 172:3138-3145.

2.Cohen-Bazire, G.S. 1988. Fine structure of cyanobacteria, p. 157-172. In L. Packer and A.N. Glazer (Eds.). Methods in Enzymology, Vol. 167, Cyanobacteria. Academic Press, New York.

3.Elhai, J. and C.P. Wolk. 1988. Conjugal transfer of DNA to cyanobacteria. In L. Packer and A.N. Glazer (Eds.), Methods in Enzymology, Vol. 167, Cyanobacteria. Academic Press, New York.

4.Higuchi, R. 1988. Simple and rapid preparation of samples for PCR, p. 31-38. In H.A. Erlich (Ed.), PCR Technology: Principles and Applications for DNA Amplification. Stockton Press, New York.

5.Howitt, C.A. 1995. Pyridine nucleotide dehydrogenases in the cyanobacterium Anabaena PCC 7120 and the chloroplasts of higher plants. Ph.D. Thesis, Australian National University.

6.Mazur, B.J., D. Rice and R. Haselkorn. 1980. Identification of blue-green algal nitrogen fixation genes by using heterologous DNA hybridisation probes. Proc. Natl. Acad. Sci. USA 77:186-190.

Financial support for this project was provided by an Australian Research Council grant to Dr. David Day, Australian National University. Thanks go to Dr. Dean Price for critical reading of the manuscript and to Kathy Smith for helpful discussions. C.A.H. was the recipient of an Australian Postgraduate Award and a Graduate Scholar Assistantship from the Cooperative Research Center for Plant Science. Address correspondence to Crispin A. Howitt, Department of Botany, Arizona State University, Box 871601, Tempe, AZ 85287-1601, USA. Internet: crip@asu.edu

Received 30 October 1995; accepted 17 January 1996.

\section{Crispin A. Howitt}

Australian National University

Canberra, Australia
Improved LigationAnchored PCR Strategy for Identification of $5^{\prime}$ Ends of Transcripts

BioTechniques 21:34-38 (July 1996)

Polymerase chain reaction (PCR)based strategies have been used for the isolation of the $5^{\prime}$ ends of mRNA transcripts $(2,4)$. Originally, a method based on homopolymeric tailing of cDNA was developed (2). Ligation-anchored PCR (LA-PCR) was subsequently devised as a more sensitive and efficient strategy (4). In LA-PCR, following first-strand cDNA synthesis, the "anchor" is ligated to the 3 ' end of the first-strand cDNA by T4 RNA ligase. An anchor-specific primer and a primer complementary to a known segment of the cDNA are then used to amplify the $5^{\prime}$ end of the transcript.

Here we describe modifications to this method that eliminate two enzymatic reactions during the preparation of the anchor and obviate the need for base/acid treatment to remove residual RNA. Furthermore, the residual oligo(dT) and random hexamers are removed by using microcolumns to prevent their ligation to the anchor. Use of a nested PCR strategy and biotinylation of the cDNA-specific primer also improve the sensitivity of the method. Overall, the changes result in a more robust and reproducible procedure.

Total RNA and mRNA were isolated from white blood cells (WBC) and various cell lines by using standard protocols (3). First-strand cDNA synthesis was performed as follows: $5 \mu \mathrm{g}$ of mRNA or total RNA were heated at $65^{\circ} \mathrm{C}$ for $3 \mathrm{~min}$ and quickly chilled on ice. The reaction was performed in a $40-\mu \mathrm{L}$ vol containing $1 \mathrm{mM}$ dithiothreitol, $50 \mathrm{mM}$ Tris- $\mathrm{HCl}$ (pH 8.3), $75 \mathrm{mM}$ $\mathrm{KCl}, 3 \mathrm{mM} \mathrm{MgCl} 2,0.625 \mathrm{mM}$ each dNTP, $3.2 \mu \mathrm{M}$ random hexamers (Pharmacia Biotech, Uppsala, Sweden), 0.75 $\mu \mathrm{M}$ oligo $\left(\mathrm{dT}_{15}\right), 14 \mathrm{U}$ of RNAguard ${ }^{\circledR}$ ribonuclease inhibitor (Pharmacia Biotech) and $20 \mathrm{U}$ of Moloney murine leukemia virus reverse transcriptase (Pharmacia Biotech) for $90 \mathrm{~min}$ at $37^{\circ} \mathrm{C}$. Reverse transcriptase was inacti- 